\title{
Література
}

1. Безрукова В.С. Педагогика. Проективная педагогика: [учеб. пособ. для инженерно-пед. инстутов и индустр.-пед. техникумов] / В.С. Безрукова. - Екатеринбург : Деловая книга, 1996. - 344 с.

2. Беспалько В.П. Слагаемые педагогической технологии / В.П. Беспалько. - М. : Педагогика, 1989. - 192 с.

3. Дж. ван Гиг «Прикладная общая теория систем» / Дж. ван Гиг: [пер. с англ.]. М. : Мир, 1981. -733 с.

4. Заир-Бек Е.С. Теоретические основы обучения педагогическому проектированию: дисс. ... докт. пед. наук / Е.С. Заир-Бек. - С.-Пб., 1995. - 410 с.

5. Крюкова Е.А. Введение в социально-педагогическое проектирование: [учеб. пособ. к спецкурсу; науч. ред. Н.К. Сергеев] /Е.А. Крюкова. - Волгоград: Перемена, 1998. - С. 57.

6. Методы системного педагогического исследования: [учеб. пособие / под ред. Н.В. Кузьминой]. - Л. : Ленинград. гос. ун-т, 1980. - 172 с.

7. Слободчиков В.И. Проблемы научного обеспечения инновационной деятельности в образовании / В.И. Слободчиков. - Киров, 2003. - 152 с.

8. Смыковская Т.К. Теоретико-методологические основы проектирования методической системы учителя математики и информатики : дис. ... д-ра пед. наук: 13.00 .02 / Т.К. Смыковская. - М., 2000. - 383 с.

9. Уемов А.И. Системный подход и общая теория систем / А.И. Уемов. - М. : Мысль, 1978. - 272 с.

10. Ченобытов В.А. Педагогическое проектирование как акмеологическая технология педагогического образования: [электронный ресурс]. - Режим доступа. URL: // http:akmeo.rus.net/index/php?id=127.

Стаття надійшла до редакції 01.06.2012 p.

УДК 371.321

А. М. Гедзик, кандидат пед. наук, доиент,

Уманський ДПУ імені Павла Тичини

\section{ВИКОРИСТАННЯ ТВОРЧИХ ГРАФІЧНИХ ЗАДАЧ У ПРОЦЕСІ ПІДГОТОВКИ МАЙБУТНІХ УЧИТЕЛІВ ТЕХНОЛОГІЙ ДО ПРОЕКТНОЇ ДІЯЛЬНОСТІ}

Гедзик А. М. Використання творчих графічних задач у прочесі підготовки майбутніх учителів технологій до проектної діяльності.

У статті проаналізовано можливості оптимізації професійної підготовки майбутніх учителів технологій до проектної діяльності засобами творчих графічних задач, які повинні базуватись на принципах, покладено в основу концепщіі системи активізації навчання $i$ які охоплюють основні аспекти навчально-виховного процесу.

Ключові слова: професійно-графічна підготовка, проектна діяльність, конструкторські знання, оптимізачія навчального прочесу, типологія задач.

Гедзык А.Н. Использование творческих графических задач в прочессе подготовки будущих учителей технологий к проектной деятельности.

В статье проанализированы возможности оптимизации профессиональной подготовки будущих учителей технологий к проектной деятельности средствами творческих графических задач, которые долюжны базироваться на принципах, что положенны в основу концепиии системы активизации обучения и которые охватывают основные аспекты учебновоспитательного процесса. 
Ключевые слова: профессионально-графическая подготовка, проектная деятельность, конструкторские знания, оптимизачия учебного прочесса, типология задач.

Gedzyk A. The use of creative graphic tasks is in the process of preparation of future teachers of technologies to project activity.

In the article possibilities of optimization of professional preparation of future teachers of technologies are analysed to project activity by facilities of creative graphic tasks, which must be based on principles, that the conceptions of the system of activation of studies fixed in basis and which embrace the basic aspects of educational-educator process.

Key words: professionally-graphic preparation, project activity, designer knowledge, optimization of educational process, типологiя of tasks.

\section{Постановка проблеми. Одним із найважливіших компонентів} удосконалення системи навчання та виховання майбутнього вчителя технологій $є$ його графічна підготовка. Сучасна педагогічна наука має значну кількість засобів і прийомів, за допомогою яких педагог-предметник залучає студентів до пізнавальної діяльності на заняттях, активізує процес їхньої розумової діяльності. Особливе місце серед них займає навчання 3 використанням творчих задач. При розробці системи творчих задач з креслення варто змоделювати умови, що вимагали б від студентів виконання перерахованих дій. Зрозуміло, у кожному конкретному випадку вони $є$ у різних поєднаннях і пропорціях, розвиваючи різні сторони творчого мислення, однак кожній задачі властива загальна ознака: алгоритм іiі рішення не відомий студентам, хоча для рішення $є$ всі необхідні дані. Як засвідчує аналіз навчально-методичної літератури, в процесі формування графічних понять майбутні учителі технологій здебільшого розв'язують задачі, рішення яких вимагає уявних перетворень форми і просторового положення об'єкта за його кресленням. Уведення цих задач у навчальний процес готує студентів до навчання елементам конструювання, формуючи своєрідну готовність інтелекту до активної розумової роботи. Однак, на нашу думку, слід звернути увагу на два важливих моменти. По-перше, перетворення заданих просторових властивостей предмета і конструювання нових - тісно пов'язані, але різні види діяльності. По-друге, задачі на перетворення не передбачають вияв творчості, оскільки їх умова регламентує одержання єдиного рішення.

Аналіз останніх досліджень і публікацій. Поняття «задача»- одне 3 основних у психології і педагогіці. Розгляд ролі і місця задач в навчальному процесі знайшли відображення в роботах О. Лсонтьєва, I. Лернера, Л. Фрідмана, Г. Балла, Д. Ельконіна. У плані нашого дослідження заслуговують на увагу психологічні аспекти розв'язування графічних задач, розкриті в роботах П. Гальперіна, Л. Фрідмана, В. Паламарчук, 3. Калмикової, В. Розумовського.

Метою статті $\epsilon$ аналіз можливості оптимізації процесу підготовки майбутніх учителів технологій до проектної діяльності шляхом впровадження творчих графічних задач, який має базуватись на принципах, які покладені в основу концепції системи активізації навчання і охоплюють основні аспекти навчально-виховного процесу.

Виклад основного матеріалу. Умова творчої задачі має визначати виникнення проблемної ситуації, а рішення - спонукати до використання 
набутих знань у нових ситуаціях, а іноді і до самостійного набуття нових. Нарешті, обов'язковою особливістю творчих задач $\epsilon$ варіативність їхнього рішення, тому що тільки в цьому випадку виникає індивідуальний пошук, логічним завершенням якого і $є$ суб'єктивно новий результат. Якщо немає вибору можливих шляхів рішення, виходить, немає вияву творчості. Такі характерні риси творчих задач i їх відмінність від задач, що мають виконавський характер. Констатуючи наявність рівнів у засвоєнні знань, В. Розумовський вказує, що ними є розуміння, запам'ятовування, застосування знань за правилом i, нарешті, розв'язання творчих нетипових задач, що вимагають застосування знань у нових умовах. Творчі задачі відповідають вищому рівню засвоєння знань, а тому повинні, як правило, завершувати собою вивчення того або іншого розділу курсу, хоча окремі елементи творчої діяльності студентів можуть супроводжувати і більш ранні етапи навчання. У цьому випадку йдеться звичайно про так звані пропедевтичні задачі, що розвивають загальну готовність студентів до проектної діяльності.

Оптимізувати процес підготовки студентів до проектної діяльності можуть, наприклад, задачі, які передбачають графічне моделювання креслення предмета 3 неповними даними. Володіючи яскраво вираженим творчим характером, вони спонукують студентів до активного пошуку, комбінаторики.

Розпочинаючи розгляд задач із креслення, що містять елементи проектної діяльності, потрібно підкреслити, що йдеться переважно про графічні елементи, тому що, у свою чергу, було б неправильним підмінювати креслення конструюванням, дизайном або архітектурою. В усіх видах творчих задач із креслення головне місце має займати графічна робота, що не вимагає спеціальних знань студентів.

Проектна діяльність майбутніх учителів технологій має аналізуватися, що дозволяє додатково виокремити під час розроблення задач ті елементи, що наповнюють навчальну працю конкретним змістом i водночас мають безпосереднє відношення до креслення. Центральне місце у системі задач має приділятись задачам, пов’язаним з конструюванням, тому що це джерело надає змогу використовувати приклади з багатьох пріоритетних напрямків науково-технічного прогресу.

Головною особливістю спільною для креслення і конструювання (як, утім, і для інших видів проектної діяльності), є уміння використовувати графічні знання в новій, конкретно заданій ситуації. Стосовно креслення це означає, що студент має правильно розуміти умову задачі, виражену мовою графіки, обирати ті методи зображень, що на визначеному етапі розв'язання задачі здатні скласти опору технічному задумові, утримати його у свідомості, послужити основою для розвитку задуму і його завершення.

Під час роботи конструкція об'єкта уточнюється, а іноді й істотно змінюється, тому студент повинний уміти вносити виправлення до створеної ним графічної опори, причому робити це відповідно до правил креслення. Іншими словами, паралельно з уявними перетвореннями форми студент має 
робити перетворення графічні. Нарешті, на завершальній стадії роботи перед студентами виникає найскладніша проблема: на кресленні необхідно грамотно відобразити підсумок творчої роботи. Варто використовувати оптимальну кількість зображень, 3 достатньою повнотою i наочністю особливості форми об'єкта. Труднощі полягають у тому, що в цей момент студенти повинні подумки перепробувати усі відомі їм методи зображень i вибрати потрібні, згадати необхідні правила і ними скористатися.

Для викладача важливо розуміти, які елементи конструкторських знань і умінь повинні бути відображені у творчих задачах з креслення і навіщо це робиться. Почнемо з останнього. Як уже відзначалося, у курсі креслення знайшли своє місце задачі на уявне перетворення форми і положення об’єкта, однак кінцевою метою цих перетворень були самі перетворення. Ніхто не заперечував ролі цих задач у розвитку образного мислення студентів, але для них самих семантичне значення перетворень, зрозуміле методистам, залишалося нерозкритим, а тому інтерес до занять не виникав.

Задачі на конструктивні перетворення мають відчутну для студентів практичну цінність, оскільки в них у доступній формі ставиться конкретна технічна мета. Прагнення до досягнення цієї мети стимулює інтерес до роботи. Які складові ж основних конструкторських знань i умінь? Підсумовуючи дані низки педагогічних досліджень, можна констатувати, що до них звичайно відносять:

1. Знання загальних вимог (функціональних, ергономічних, естетичних i ін.), пропонованих до конструкцій.

2. Уміння читати і виконувати креслення.

3. Уміння вибрати оптимальну форму і розміри деталей.

4. Уміння вибрати матеріал.

5. Знання способів оброблення.

6. Уміння робити необхідні розрахунки.

7. Знання типових способів з'єднання деталей.

8. Уміння користуватися стандартами і довідковою літературою.

9. Уміння робити аналіз створених конструкцій.

10. Знання правил техніки безпеки в роботі з механізмами.

Аналізуючи приведений перелік, з'ясовуємо, що крім власне графічних знань і умінь логіці креслення відповідають і багато інші. Під час розроблення творчих задач з елементами конструювання важливий вибір об'єкта. Однак тут виникають певні труднощі. По-перше, для початкових етапів навчання потрібно підбирати не специфіковані об'єкти, тобто одно детальні предмети, виготовлені без застосування складальних операцій. Однак відомо, що їх значно менше, ніж об'єктів, що складаються з двох і більш деталей. По-друге, потрібно вибирати предмети, форма яких становить інтерес з погляду графічної діяльності. Бажано також, щоб форма була сучасною (не застаріла морально) i, нарешті, щоб об'єкт можна було виготовити на базі майстерень. Такі ж вимоги висуваються до специфікованих об'єктів.

Під час аналізу відомих видів робіт, що рекомендуються у процесі навчання конструюванню, виявилося, що найбільш близькими до логіки креслення $є$ : 
1) заповнення відсутньої ланки конструкції (доконструйовання);

2) удосконалення конструкції на основі аналізу прототипу (переконструювання);

3) конструювання за технічними умовами (із предметно-графічною опорою).

Перераховані види навчальної роботи активізують процеси навчання кресленню, оскільки вони найбільше тісно пов'язані 3 використанням графічних зображень. Окрім того, вони різняться більшою простотою в порівнянні з конструюванням за схемою або за власним задумом.

В основі доконструювання, переконструювання і конструювання за технічними умовами, як специфічних видів конструктивно-графічної діяльності студентів, лежать пошуки технічних рішень i їх графічне відображення. В останні роки розроблено значну кількість методів пошуку нових технічних ідей і рішень. Методи, про які йдеться, дозволяють раціоналізувати різні аспекти пошукової діяльності.

Передумови їх виникнення зв'язані з ускладненням сучасного процесу проектування, і в першу чергу з ускладненням вибору оптимального рішення 3 безлічі можливих. Розроблені до даного часу методи можуть бути використані для розв'язання пошукових задач як окремим проектувальником (морфологічний аналіз, метод Метчетта), так і спеціально формованим пошуковим колективом (метод «мозкового штурму», сенектика й ін.).

Тривалий час процес висування нових ідей вважався неформалізованим. Ця думка підтримувалася як науковцями-психологами, що вивчали творчість, так і самими розробниками. Однак виникнення потреби в активізації розробки ідей і рішень змусило змінити цю позицію.

У технічній творчості підвищення темпів і якості роботи було досягнуто в першу чергу за рахунок поділу його на окремі стадії. У цьому плані найбільше поширення одержав метод технічних рішень за назвою «алгоритм рішення винахідницьких задач». У межах цього методу вперше організовано спрямований пошук рішення технічних задач.

Центральним ядром у переліку упорядкованої послідовності дій (алгоритму) є виявлення й усунення технічної суперечності, що, як правило, виникає через те, що спроба поліпшити які-небудь властивості об'єкта вступає в конфлікт 3 іншими його властивостями. Отже, технічна суперечність, властива конкретній задачі, вказує на перешкоду, яку потрібно перебороти в ході іiі рішення. Відповідно до методики алгоритму рішення винахідницьких задач, розробленої С. Альтшулером, схема творчого процесу передбачає на три стадії - аналітичну, оперативну, синтетичну. Перша 3 них пов'язана 3 вибором задачі і пошуками основної суперечності, друга - 3 дослідженням типових, уже відомих прийомів рішення або пошуками нових, третя - із введенням функціональних змін до об'єкта і методами його використання.

За умови визначених змін, викликаних специфікою навчальної роботи, особливостями предмета і можливостями студентів, на основі методики алгоритму рішення винахідницьких задач можна будувати навчання 3 
використанням прийомів пошуку технічних рішень. Однак цей пошук спирається на графічну діяльність, що невіддільна від роботи конструкторів, раціоналізаторів, винахідників на всіх іï етапах. Як зазначає Е. Сурін, «уява конструктора i виконуване ним креслення постійно перебувають у діалектичній взаємодії і взаємно доповнюють один одного, тому що конструктор не може утримувати у свідомості настільки ясні і стійкі просторові образи, щоб оперувати ними, не повертаючись до креслення. У цьому відношенні конструювання без креслення можна було б порівняти 3 грою в шахи без дошки» [5].

Нерозривність конструкторської і власне графічної діяльності вимагає того, щоб у навчальному процесі, що моделює працю професіоналів, був відображений логічний зв'язок між пошуком технічних рішень i графічним відображенням.

У процесі розроблення змісту творчих задач і методичних рекомендацій 3 їхнього використання в навчальному процесі важливо враховувати ті характерні риси, що супроводжують конструкторсько-графічну діяльність студентів. По-перше, необхідно знати, якою мірою студенти зможуть використовувати сформовані в них раніше графічні знання, по-друге, розуміти, які характерні труднощі виникають у процесі творчої роботи і як попередити них. Під час дослідження особливостей рішення учнями творчих задач з елементами конструювання варто звернути увагу на таке:

1. Труднощі студентів починаються з невміння аналізувати вихідні дані задачі (знайти основне протиріччя конструкції, зрозуміти, яким вимогам має відповідати відсутня деталь і як вона має працювати), іншими словами, 3 відсутності аналітичних здібностей. Це негативно позначається на пошуковій діяльності і в остаточному підсумку зумовлюють нераціональне рішення задачі.

2. Труднощі і помилки, що допускаються студентами при графічному відображенні конструкторського задуму, в основному пов'язані з невмінням використовувати сформовані раніше графічні знання в новій ситуації. Конкретно це виражається у:

а) невмінні вибрати оптимальну кількість зображень 3 необхідною повнотою і наочністю, що розкривають особливості конструкцій;

б) невмінні вибрати масштаб зображень, що дозволяє виділити головне в конструкції;

в) труднощах із розміщенням зображень на кресленні;

г) помилках, пов’язаних із порушенням загальних правил креслення.

3. Характерним етапом графічного пошуку $є$ виконання студентами зображень, у яких, як правило, закладена перша спроба зафіксувати виникле у свідомості ядро майбутньої конструкції.

Нерідко опорні зображення використовуються i на інших стадіях пошуку, аж до його завершення. У цьому випадку ядро конструкції поступово ускладнюється суміжними деталями, що до визначеного часу не скріплені з ядром, а лише згруповані довкола нього. 
Опорні зображення студент виконує лише для себе і прагне не показувати їх викладачу, тому що ідея, закладена в них, пердбачає серйозні порушення правил креслення. Для студента це чернетка. Викладачу подається вже певною мірою відкоректований варіант креслення. Проте навіть у ньому спостерігається вплив опорних зображень. У процесі виконання креслень студенти використовують переважно ортогональні проекції, що іноді помилково поєднується 3 елементами аксонометрії. Розрізи застосовуються рідше, перерізи - майже ніколи.

Під час складання умов задач варто враховувати можливість виникнення різних труднощів, з якими студенти можуть зустрітися при їх вирішенні.

Так, для вивчення вихідної конструкції подається умова задачі, спрямованої на одержання найпростішого кінцевого результату. Примітка відкриває шлях до розроблення конструкцій, що мають більш широкі можливості, однак тут же пошук лімітується тим, що виріб мав складатися 3 однієї деталі. Зумовити це дуже важливо, тому що серед студентів, що не вивчали складальних креслень, можуть з'явитись бажаючі розробити специфікований виріб, які не знають, як його накреслити.

Висловлюючи побажання щодо формулювання умов задач, зауважимо таке. До тексту умов доцільно включати кілька пунктів, що передбачають виконання робіт, різних за складністю. Це дозволяє використовувати їх на різних етапах навчання і виконувати роботи з урахуванням індивідуальних можливостей студентів.

Висновки. Педагогічна практика показує, що використання творчих графічних задач в професійно-графічній підготовці майбутніх учителів технологій можливе при вивченні переважної більшості тем навчальної програми курсу «Нарисна геометрія та креслення». На нашу думку, вже 3 перших занять дисциплін професійно-графічної підготовки під час упровадження творчих графічних задач у навчальний процес не слід забувати i про те, що досвід опанування елементарними графічними знаннями уміннями і навичками майбутні фахівці, переважна більшість яких, до речі, не мала змоги вивчати систематичний курс креслення в загальноосвітній школі, використовуватиме у своїй професійній діяльності. Як засвідчують результати проведеної роботи, використання розглянутих теоретичних положень сприятиме оптимізації процесу підготовки майбутніх учителів технологій до проектної діяльності.

Актуальними напрямками подальшого розроблення окреслюваної проблеми $\epsilon$ вивчення питання щодо можливостей використання сучасних технічних засобів у процесі впровадження творчих графічних задач на різних етапах підготовки майбутніх учителів технологій до проектної діяльності.

\section{Література}

1. Ботвинников А.Д. Научные основы формирования графических знаний умений и навыков школьников / А.Д. Ботвинников, Б.Ф. Ломов. - М. : Педагогика, 1979. - 255 с.

2. Вышнепольский И.С. Методика преподавания черчения / И.С. Вышнепольский, Л.И. Тржецяк. - М. : Профтехиздат, 1962.-231 с. 
3. Ломов Б.Ф. Формирование графических знаний и навыков у учащихся / Б.Ф. Ломов.- М. : Политиздат, 1959. - 267с.

4. Менчинская Н.А. Психология применения знаний к решению учебных задач / Н.А. Менчинская // Психология применения знаний к решению учебных задач. - М. : Изд-во АПН РСФСР, 1958. - 416 с.

5. Ройтман И.А. Методика преподавания черчения/ И.А.Ройтман. - М. : Гуманит.изд.центр ВЛАДОС, 2000. - 240с.

Стаття надійшла до редакції 01.06.2012 р.

УДК 6(07)

Н. В. Дубова, кандидат пед. наук, доцент,

Уманський ДПУ імені Павла Тичини

\section{ПСИХОЛОГО-ПЕДАГОГІЧНІ ОСНОВИ ФОРМУВАННЯ ЕЛЕМЕНТІВ ДИЗАЙНЕРСЬКОГО МИСЛЕННЯ СТАРШОКЛАСНИКІВ НА УРОКАХ ТЕХНОЛОГІї}

Дубова Н.В. Психолого-педагогічні основи формування елементів дизайнерського мислення старшокласників на уроках технології.

У статті розглянуто та проаналізовано сукупність психолого-педагогічних умов формування елементів дизайнерського мислення старшокласників на уроках технології.

Ключові слова: дизайнерське мислення, мистецька освіта, вчитель технології, старшокласники, художньо-конструкторська діяльність.

Дубова Н. В. Психолого-педагогические основы формирования элементов дизайнерского мыциления старшеклассников на уроках технологи.

В статье рассмотрен и проанализирован комплекс психолого-педагогических условий формирования элементов дизайнерского мышления старшеклассников на уроках технологии.

Ключевые слова: дизайнерское мышление, художественное образование, учитель технологии, старшеклассники, художественно-конструкторская деятельность.

Dubova N. Psychological and pedagogical basis for the formation of elements of design thinking in the classroom high school technology.

In the article considers and analyzes the complex psychological and pedagogical conditions of the elements of design thinking senior pupils technologies.

Key words: design thinking, art education, technology teacher, high school students, art and design activities.

Постановка проблеми. Залучення учнів до основних видів проектнотехнологічних робіт дозволяє долати усе нові й нові перепони на шляху пізнання, тобто оволодівати усе складнішими знаннями, вміннями й навичками. Розвиток учнів відбувається значно ефективніше, якщо в процес навчання вводяться елементи творчості та використовується художньоконструкторський підхід до виконання об'єктів праці, що позитивно впливає на підготовку і виховання молодого покоління.

Актуальність дослідження. Для розв'язання задач естетичного i трудового виховання наявні різноманітні педагогічні засоби. Серед них художньо-конструкторська діяльність посідає одне 3 провідних місць, оскільки дозволяє розв'язувати ці питання комплексно. Вироби художньоконструкторського мистецтва органічно поєднують в собі естетичний i 